\title{
MOLLUSCAN ASSEMBLAGES IN LATE HOLOCENE DEPOSITS IN BUSKO-ZDRÓJ (NIDA BASIN, SOUTHERN POLAND)
}

\author{
Witold Pawel ALEXANDROWICZ \\ \& Magdalena GOLAS-SIARZEWSKA
}

\author{
AGH University of Science and Technology, Faculty of Geology, \\ Geophysics and Environmental Protection, \\ Department of Environmental Analysis, Cartography and Economic Geology; \\ al. Mickiewicza 30, 30-059 Krakow, Poland; \\ e-mail: wpalex@geol.agh.edu.pl,mgolas@agh.edu.pl
}

\begin{abstract}
Late Holocene deposits containing abundant and well-preserved malacofauna were exposed within the Spa Park in Busko-Zdrój. Molluscan shells were found in sand, dark muds and calcareous muds. Dark and calcareous muds are intercalated by fine-grained sand and peat devoid of malacofauna. All these deposits were accumulated on swampy, flat bottom of wide river valley. The result of radiocarbon dating has shown that the formation of the deposits started in the upper part of the Subboreal Phase. Numerous Late Medieval pottery shards were found in several topmost profile sections. The identified malacofauna suggests that similar climatic and habitat conditions prevailed throughout the entire sedimentation period. Snails typical of open habitats, accompanied by hygrophilous taxa, play a dominant role. Mesophilous and aquatic taxa occur in accessory proportions, while shadow-loving forms are virtually absent.
\end{abstract}

Key words: malacofauna, peat bog, Late Holocene, Nida Basin, South Poland

\section{INTRODUCTION}

The Nida Basin is a depression in the form of an asymmetric synclinorium filled with Late Cretaceous and Miocene deposits covered by diverse sedimentary facies of the Quaternary (Rutkowski 1986). Between Pińczów and Busko there is a rise formed mainly by the Late Cretaceous marls, called the Pińczów hummock. The rise extends in a NW-SE direction, over a distance of approximately $42 \mathrm{~km}$ and reaches a maximum altitude of $293 \mathrm{~m}$ a.s.l. 
It has a plateau on top and its slopes are steep, carved with numerous valleys and ravines, often featuring considerable drops in altitude (Radłowska 1966, Cabaj \& Nowak 1986). A flat area spreads south of the Pińczów hummock, where small peatbogs have developed. Peat often creates an acidic environment (low $\mathrm{pH}$ values). Such conditions usually lead to the rapid dissolution of calcium carbonate. In some cases, however, carbonate deposits are accumulated in the peat substrate, and the waters penetrating the peat bog are distinctly alkaline. This enables the preservation of molluscan shells in a sub-fossil state. Such peat bogs, containing intercalations of calcareous tufas or lacustrine chalks and fairly abundant malacofauna, were described at several sites in Poland (e.g. S.W. Alexandrowicz et al. 1994, W.P. Alexandrowicz 1997, 1999, 2004, Dobrowolski et al. 2005, 2012). The Quaternary deposit profiles in Busko-Zdrój represent an example of such a site.

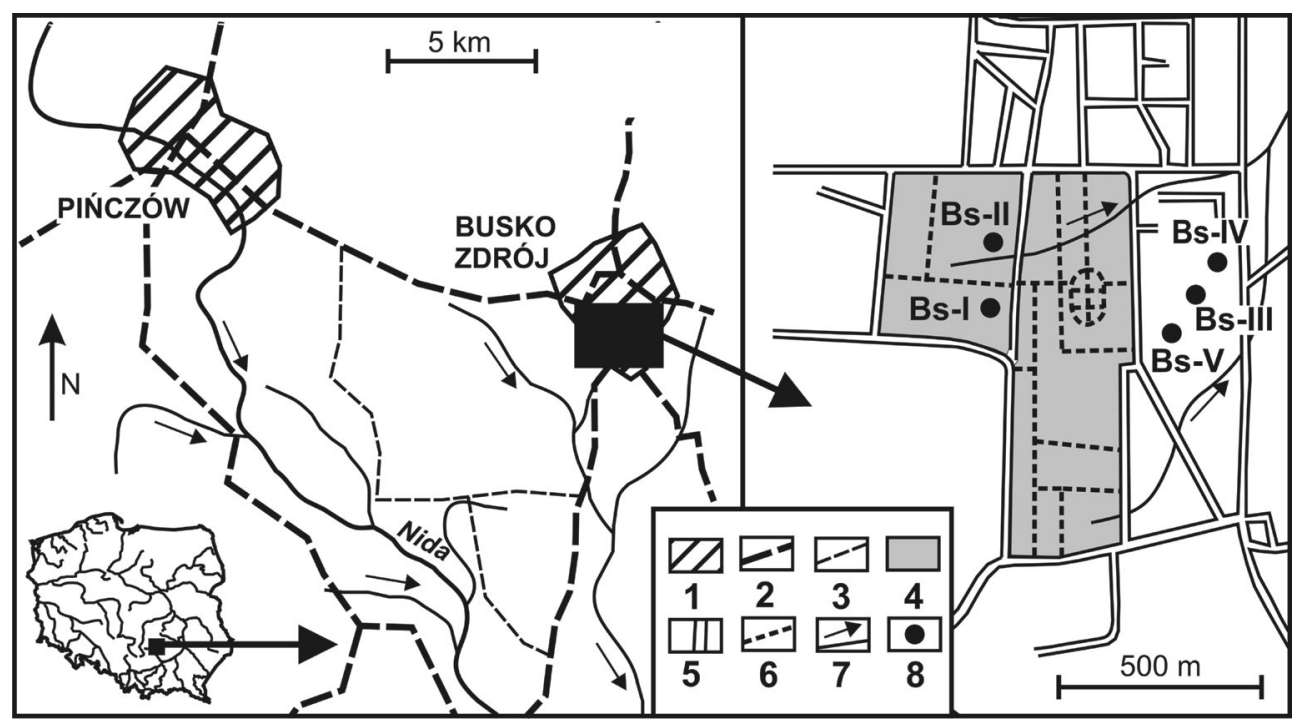

Fig. 1. Location of the site and described profiles: 1 - towns, 2 - main roads, 3 - other roads, 4 - Spa Park in Busko-Zdrój, 5 - streets, 6 - park alleys, 7 - rivers and streams, 8 - analyzed profiles

The profiles subject to analysis were exposed during excavation work carried out in the Spa Park in the centre of the town. Five profiles in total were studied (Fig. 1). They are all located on a very flat, wide terrace of a small stream. Currently it is being gradually reclaimed, drained and used for building development. It is a waterlogged, mire-like area, and may be partially inundated during periods of increased precipitation. The appearance of small seasonal water bodies can be ascribed to periodical elevation in the groundwater table. The profiles are currently unavailable for observation.

The major objective of the study conducted in Busko-Zdrój was to reconstruct the changes in the natural environment during the sedimentation of these deposits. Of par- 
ticular interest was the opportunity to describe human impact. Quite a few remnants of manmade artefacts representing different historical periods occurred in the analysed profiles.

\section{MATERIALS AND METHOD}

The material for malacological study was taken from five profiles situated at relatively small distance from one another (Fig. 1). The deposit samples were obtained from each profile. They covered $20 \mathrm{~cm}$-thick intervals and weighed $2 \mathrm{~kg}$ each. The samples were subjected to the flushing of rocks on a $0.5 \mathrm{~mm}$ mesh, and after drying all entirely preserved molluscan shells were collected, including both adult and juvenile forms, as well as fragments of shells that could easily be identified with the species rank. The latter were calculated into whole specimens, in accordance with the formula proposed by S.W. Alexandrowicz (1987).

Nineteen samples were collected from the five profiles presented below. All contained molluscan shells. The number of taxa varied between samples from 9 to 28 , whereas the number of specimens spread from 77 to 7532 respectively (Figs 2N, 3N). A total of 35 molluscan species, including four bivalve species, were found in all profiles from Busko-Zdrój. The entire material identified comprised 25885 specimens. The composition of malacofauna is presented in Table 1.

The malacological analysis was performed using standard methods described by Ložek (1964), S.W. Alexandrowicz (1987) and S.W. Alexandrowicz \& W.P. Alexandrowicz (2011). The ecological demands of particular snail and bivalve species were determined based on numerous studies (among others, Ložek 1964, 2000, Piechocki 1979, Piechocki \& Duyduch-Falniowska 1993, Wiktor 2004). Individual species were classified into ecological groups: $\mathrm{F}$ - shade-loving species, $\mathrm{O}$ - species of open spaces (meadow species), $\mathrm{M}$ - mesophilous species, $\mathrm{H}$ - hygrophilous species, $\mathrm{T}-$ species of episodic bodies of water and $\mathrm{P}$ - species of permanent bodies of water. The percentage proportions of individual species and ecological groups enabled us to develop malacological diagrams. The stratigraphic position of the deposits exposed in Busko was determined using radiocarbon dating and archaeological dating of the pottery shards found. The radiocarbon analysis was performed at the Department of Radioisotopes, the Institute of Physics of the Silesian University of Technology at Gliwice.

\section{GEOLOGICAL SETTING}

The Bs-I profile is located between ten and twenty metres west of the Spa Park, a little north of Rokosza Street (Fig. 1). 


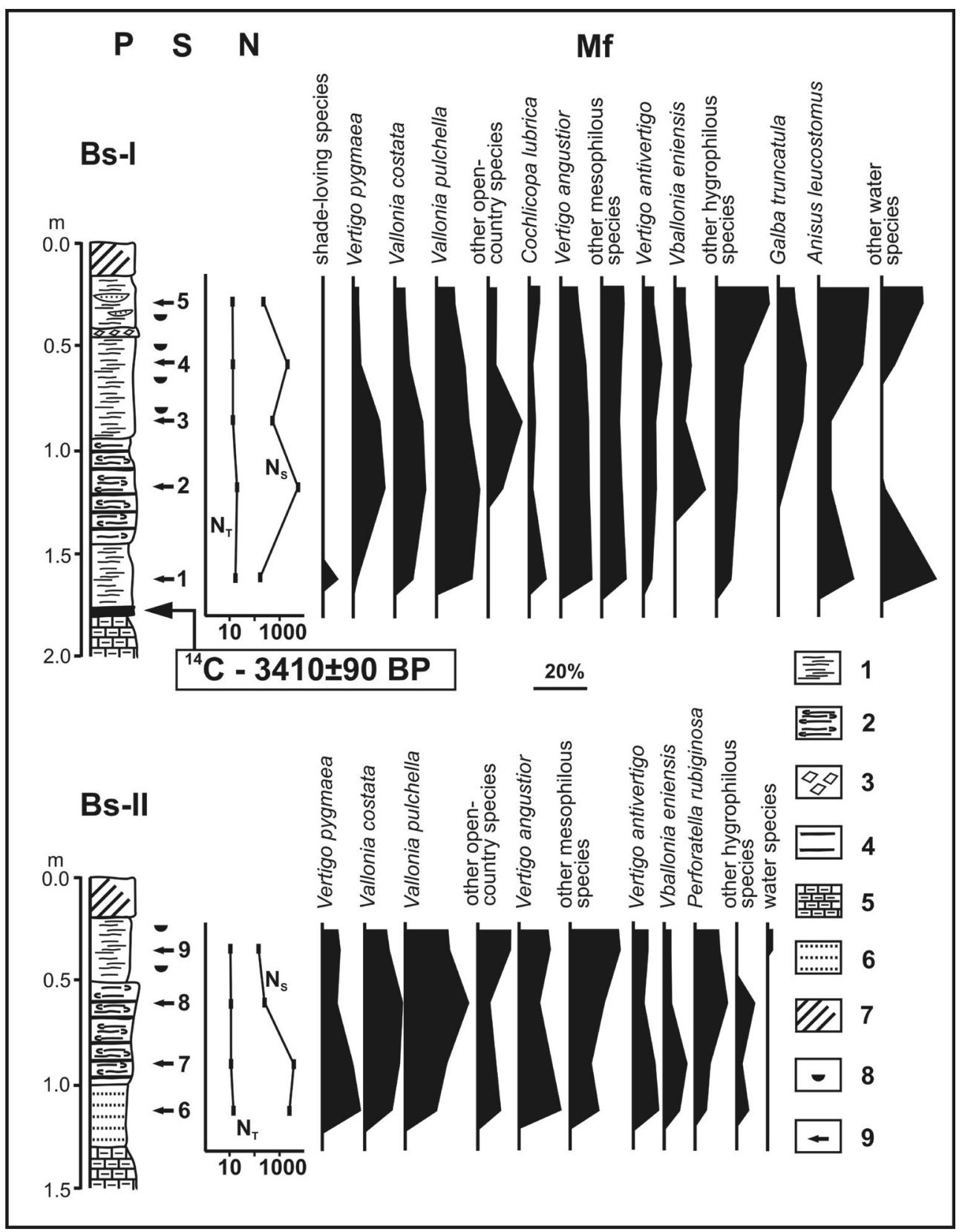

Fig. 2. Lithology and malacofauna of sections Bs-I and Bs-II: P - profiles - lithology: 1 - muds, 2 - calcareous muds, 3 - pebbles of Cretaceous marl, 4 - peat, 5 - Cretaceous marl, 6 - sand, 7 - recent soil, 8 - pottery sherds, 9 - samples; $\mathrm{S}$ - samples; $\mathrm{N}$ - number of taxa $\left(\mathrm{N}_{t}\right)$ and specimens $\left(\mathrm{N}_{\mathrm{s}}\right)$; Mf - malacofauna 


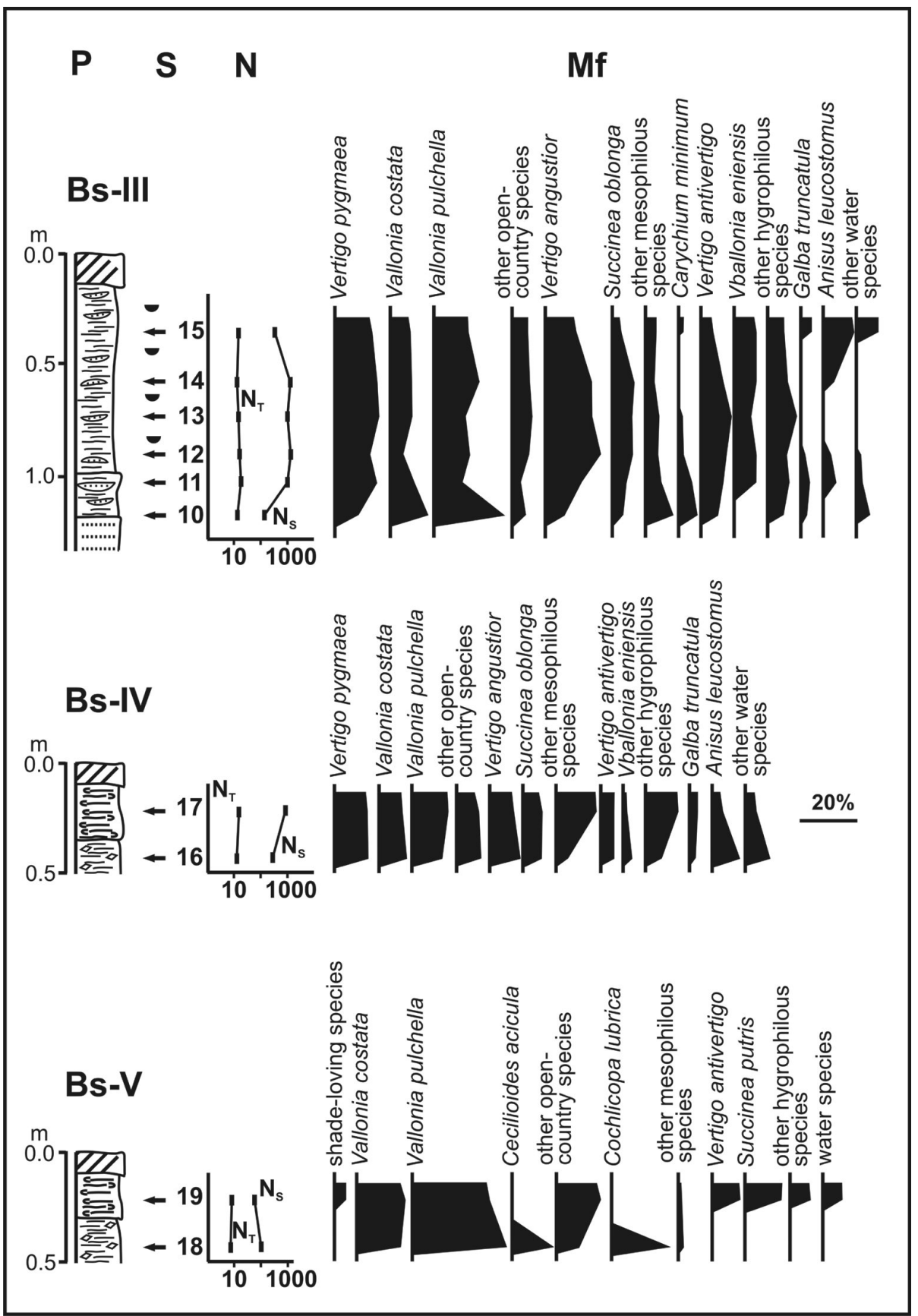

Fig. 3. Lithology and malacofauna of sections Bs-III, Bs-IV and Bs-V. For explanations see Figure 2 


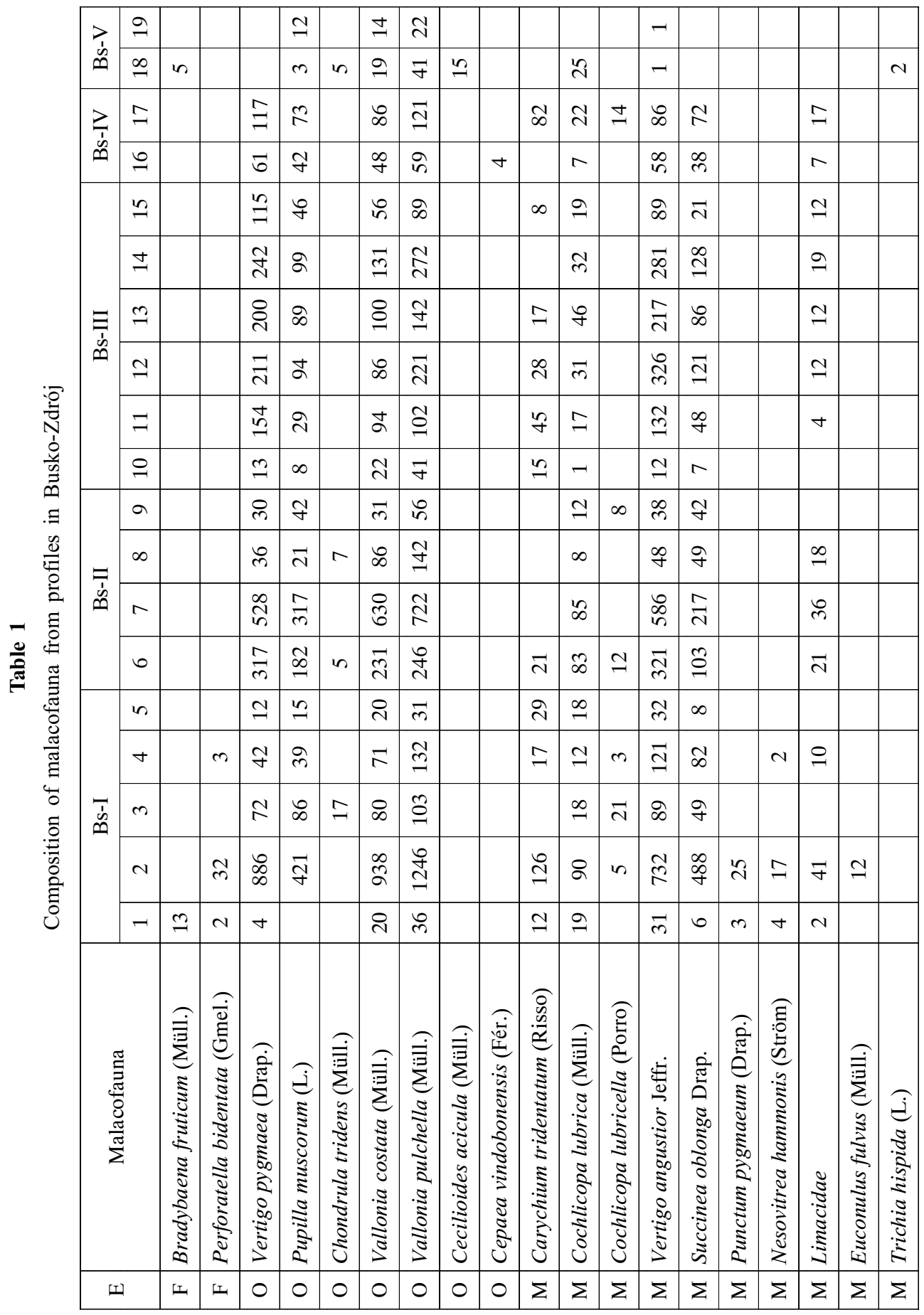




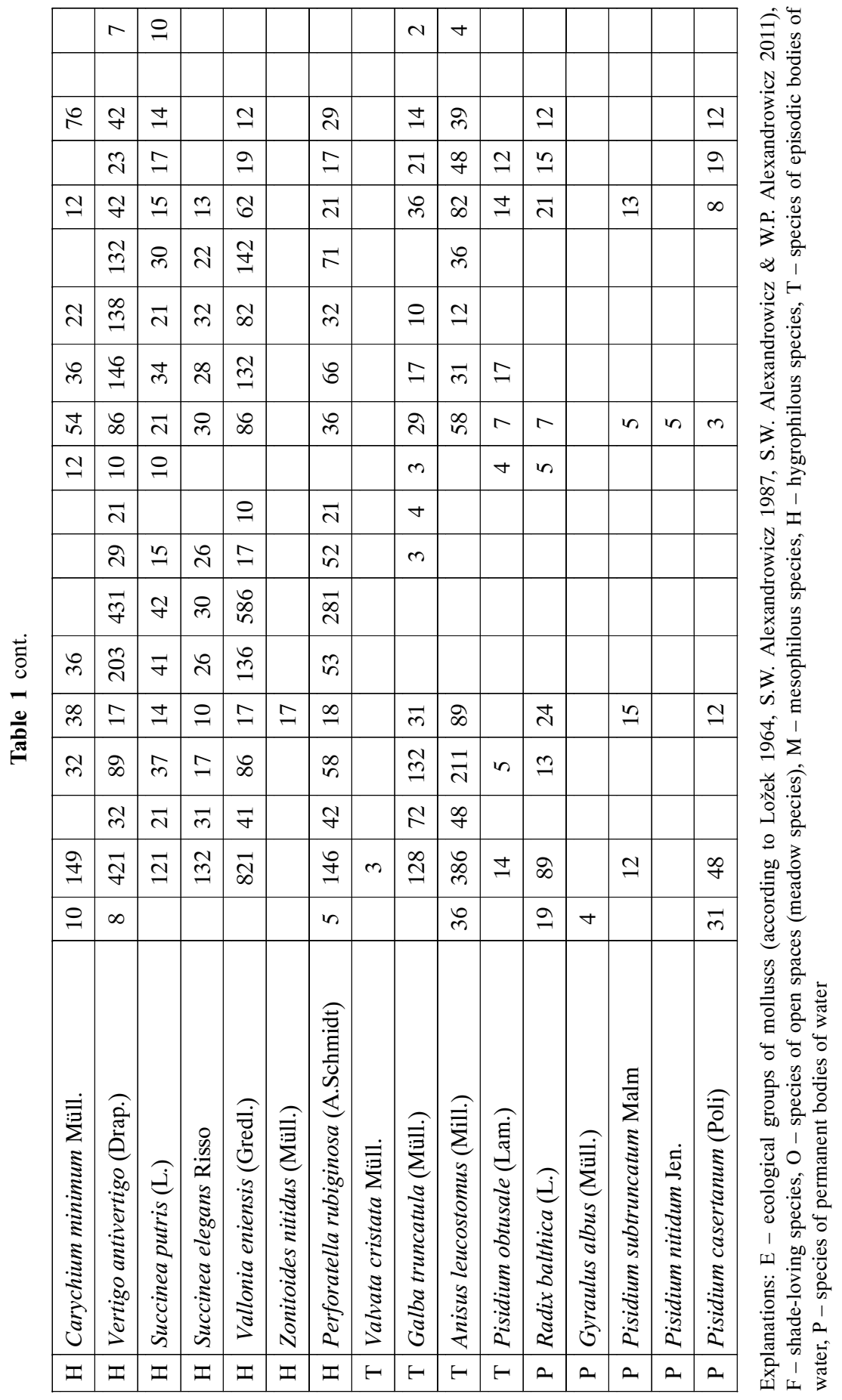


The profile is $2 \mathrm{~m}$ thick and, starting from the top, the following sections can be distinguished (Fig. 2P):

- 0.00-0.15 m - recent soil;

- $0.15-0.40 \mathrm{~m}$ - grey muds, mildly gritty and containing small lenses of fine-grained sand; decayed tree fragments and molluscs shells are present; a rusty nail was found in one of such fragments; crushed brick and pottery sherds occur as well;

- $0.40-0.45 \mathrm{~m}$ - boulder pavement formed by Cretaceous marl pebbles, $1-1.5 \mathrm{~cm}$ in size;

- 0.45-0.95 m - dark grey, in some places black, organic mud, strongly cohesive, with clearly marked vertical cracks and molluscs shells; fragments of crushed medieval ceramics and bricks were found in this layer;

- 0.95-1.45 m - dark grey calcareous muds with scarce knobs, interbedded with 2-3 cm thick peat layers; in muds shells of molluscs were found;

- 1.45-1.75 m - grey and ash-coloured muds with traces of lamination and malacofauna;

- $1.75-1.80 \mathrm{~m}$ - black peat with numerous fragments of tree branches; the organic material obtained from one of the peat intercalations was radiocarbon-dated to $3410 \pm 90$ years BP (1938-1509 cal BC) (Gd-2940);

- 1.80-2.00 m - white Cretaceous marl.

The Bs-II profile is located between 10-20 m west of the Spa Park, north of Rokosza Street, approximately $100 \mathrm{~m}$ north of the Bs-I profile (Fig. 1). The profile is $1.5 \mathrm{~m}$ thick and, starting from the top, the following sections can be distinguished (Fig. 2P):

- $0.00-0.20 \mathrm{~m}$ - recent soil;

- $0.20-0.55 \mathrm{~m}$ - dark grey, vaguely laminated muds with Cretaceous marl clasts, malacofauna and numerous medieval pottery shards;

- $0.55-1.00 \mathrm{~m}$ - grey calcareous mud, mildly gritty in the bottom part; a $2.5 \mathrm{~cm}$ thick peat layer occurs in the middle part; in muds shells of molluses were found;

- 1.00-1.30 m - white fine-grained sand with numerous shells of molluscs;

- 1.30-1.50 m - Cretaceous marl.

The Bs-III, Bs-IV, and Bs-V profiles are situated east of the Spa Park (Fig. 1). They lie in a wide, flat-bottomed basin underlain by the Cretaceous marl, in some places covered by fine patches of the Miocene formations. The thickness of the Quaternary deposits in this area reaches its maximum at $1.5 \mathrm{~m}$, and usually does not exceed $1.0 \mathrm{~m}$. The drainage works exposed the Holocene formation profiles in many places. The profiles Bs-III, Bs-IV and Bs-V are located within such excavation pits. The Bs-III site is situated in the zone where the Holocene formations reach their greatest thickness. Starting from the top part, the following sections were recorded (Fig. 3P):

- $0.00-0.15 \mathrm{~m}$ - recent soil;

- 0.15-1.00 m - black organic mud with molluscs shells containing fine-grained sand lenses and streaks, and a small number of quartz grains;

- 1.00-1.20 m - dark grey muds with fine-grained sand lenses and malacofauna;

- 1.20-1.35 m - white, fine-grained, mildly calcareous sand. 
The Bs-IV and Bs-V profiles are located a short distance from the Bs-III profile (Fig. 1). The thickness of Holocene deposits does not exceed $0.5 \mathrm{~m}$. Both profiles have similar lithological features. Dark muds containing 15-20 cm thick Cretaceous marl clasts are evident in the bottom sections. They are covered with grey calcareous mud reaching $20 \mathrm{~cm}$ in thickness and with the Recent soil (Fig. 3P). Molluscs shells were found in muds both dark and calcareous.

\section{RESULTS}

Five samples containing malacofauna were obtained from the Bs-I profile (Fig. 2S). The molluscan assemblage has a relatively low diversity of species composition (the number of species per sample ranges from 16 to 28 ) and very large numbers of specimens (2657530) (Fig. 2N).

Species typical of shaded habitats are represented by only two forms with small numbers of specimens. They are most prominent in the lower part of the profile, but even there they constitute merely 3\% of the assemblage (Fig. 2Mf). Very abundantly represented are species of open spaces, of which the most commonly found ones are Vallonia pulchella and Vertigo pygmaea. This ecological group is represented in a particularly large proportion in the middle part of the profile (Fig. 2Mf). The frequency of mesophilous species is largely equal throughout the profile (Fig. 2Mf) and amounts to slightly more than $20 \%$. Forms preferring relatively moist habitats, Succinea oblonga and Vertigo angustior, are the most significant in this group. The proportion of hygrophilous snails increases manifestly towards the uppermost part of the profile, reaching 30\% (Fig. 2Mf). The dominant role among moisture-loving species is played by: Vertigo antivertigo, Succinea putris, and Perforatella rubiginosa. Aquatic taxa are represented by snails, among which Anisus leucostomus and Galba truncatula are the most significant. Bivalves are of secondary importance. All aquatic species are the forms occurring mainly in seasonal water bodies, and often even highly waterlogged terrestrial biotopes. The proportion of aquatic element reaches $35 \%$ in the top and bottom parts of the profile, while dropping to $15 \%$ in the middle interval (Fig. 2Mf).

The analysis of the alterations in the faunistic assemblage composition indicates that open biotopes have been sustained, whereas shaded habitats have played a minor role, affecting only the lower part of the profile. Nonetheless, the sequence in question is marked by fairly clear humidity alterations. The increased proportion of hygrophilous and aquatic forms, typical of disappearing water bodies, is evident in the top and bottom parts of the sequence.

Four samples containing malacofauna were collected from the Bs-II profile (Fig. 2S). These include mud samples, given that molluscan shells did not occur in the sand. The number of species per sample varied between 12 and 18, with the number of specimens ranging from 315 to 4491 respectively (Fig. $2 \mathrm{~N}$ ). 
Species typical of shaded habitats do not occur in the discussed profile. Snails of open spaces are a dominant group. The most abundant species are: Vallonia pulchella, Vallonia costata, Vertigo pygmaea and Pupilla muscorum. The presence of Chondrula tridens is particularly noteworthy. This species is typical of dry and highly insolated habitats (Fig. 2MF). The proportion of mesophilous forms fluctuates between 20 and 30\%. The most essential role is played by Cochlicopa lubrica and the forms requiring slightly more humid environment: Succinea oblonga and Vertigo angustior (Fig. 2Mf). Moisture-loving snails occur in greatest numbers in the lower part of the profile, with gradually decreasing occurrence towards the uppermost section, and the most essential ones are: Vertigo antivertigo, Vallonia eniensis and Perforatella rubiginosa. Aquatic species are represented solely by Galba truncatula and have accessory importance (Fig. 2Mf).

The malacological sequence of the Bs-II profile indicates minor environmental changes during the time of sedimentation. Relatively dry, open biotopes have constantly been predominant throughout the entire period. A small increase in habitat humidity can be noted only in the uppermost part of the profile.

Six samples containing malacofauna were collected from the Bs-III profile (Fig. 3S). The number of species in each sample varied within the range 14-22, and the numbers of specimens varied from 163 to 1639 . A considerable decrease in the assemblage specimen number is evident in the bottom section of the profile (sample Bs-11) (Fig. 3N).

The malacofauna does not contain species of shaded environments. The most essential group are the snails of open habitats: Vallonia pulchella, Vallonia costata, Vertigo pygmaea, Pupilla muscorum, whose predominance is particularly distinct in the lower part of the profile (Fig. 3Mf). Mesophilous forms occur in largest numbers in the middle interval (Vertigo angustior, Succinea oblonga, Limacidae, Carychium tridentatum) (Fig. 3Mf). Hygrophilous snails are a substantial component of the assemblage and the largest numbers of them are found in its central part. The most essential role in this group is played by Vertigo antivertigo, Vallonia eniensis, Succinea putris, Succinea elegans and Perforatella rubiginosa (Fig. 3Mf). Aquatic molluscs are represented both by snails and bivalves. They occur in the entire profile, but most abundantly in its uppermost part (Fig. 3Mf). Apart from the common Anisus leucostomus, such species as Galba truncatula, and bivalves of the genus Pisidium (Pisidium obtusale) can be found.

The ecological structure of the malacofauna identified in the Bs-III profile suggests the predominance of open and dry habitats in the bottom interval. The progressive moistening becomes visible towards the top, highlighted by the increasing significance of hygrophilous forms. The substantial proportion of aquatic molluses in the topmost part of the sequence may indicate the development of small, shallow, seasonal water bodies.

Two samples containing molluscan shells were obtained from the Bs-IV profile (Fig. 3S). The numbers of species were 16 (Bs-17) and 17 (Bs-18), and the numbers of specimens 515 and 940 respectively (Fig. 3N).

Similarly to the profiles Bs-II and Bs-III, shadow-loving species do not occur. The proportion of snails of open spaces exceeds $40 \%$ (Fig. 3Mf). Commonly found are: Vallonia 
pulchella, Vallonia costata, Pupilla muscorum and Cepaea vindobonensis. Aquatic molluscs represent a second important component of the discussed malacocoenosis (Fig. 3Mf). Frequent species are Vertigo angustior and Succinea oblonga. The forms preferring moist and waterlogged habitats are of low significance (Fig. 3Mf) (Vertigo antivertigo, Succinea putris, Perforatella rubiginosa). However, species inhabiting highly waterlogged terrestrial biotopes and seasonal water bodies, Anisus leucostomus, Galba truncatula, as well as aquatic molluscs with broad ecological tolerance, Pisidium casertanum, occur in relatively large numbers. The proportion of aquatic element is the highest in the lower part of the profile (Bs-16 sample) (Fig. 3Mf).

Two samples (Bs-18 and Bs-19) containing molluscan shells were collected from the Bs-V profile (Fig. 3S). The malacofauna was relatively sparse. Nine species were found in each sample. The numbers of specimens were 116 (Bs-18) and 77 (Bs-19) (Fig. 3N).

Shade-loving species represented by Bradybaena fruticum occurred in the Bs-18 sample (Fig. 3Mf). The dominant role in the assemblage described is played by forms typical of open habitats (Fig. 3Mf). Aside from Vallonia pulchella and Vallonia costata, which are common throughout the profile, an interesting fact is the presence of species associated with dry and highly insolated biotopes (Chondrula tridens and Cochlicopa lubricella) in the Bs-18 sample. The occurrence of Cecilioides acicula is particularly intriguing. It is a form characteristic of areas that are subject to land use. This snail lives solely in ploughed soil. Mesophilous species are a supplementary element of the assemblage in the Bs-18 sample, and they decrease in numbers towards the topmost section, where they nearly disappear (Fig. 3Mf). Moisture-loving and aquatic snails occur in the Bs-19 sample exclusively and are of secondary importance (Fig. 3Mf).

The Bs-IV and Bs-V profiles show similar sequences of malacocoenoses. They are characterised by the predominance of forms typical of open spaces. The increased proportion of moisture-loving snails and aquatic species in the Bs-V uppermost section is likely to be explained by local conditions.

\section{DISCUSSION AND CONCLUSIONS}

Malacofauna identified in the five profiles in the Busko-Zdrój site is marked by a relatively low diversity, both in terms of species composition and ecological structure. This is demonstrated by a dense distribution of points projected on a three-component diagram (Fig. 4). Nearly all the samples fit within the field of mixed faunas, with a shift towards the assemblages of open spaces with diverse humidity. This finding proves relatively small changes of environmental conditions during the sedimentation of deposits.

The age of the studied formations was determined on the basis of several derivatives. The first and most important one was the result of radiocarbon dating performed in the sample collected from the bottom part of the Bs-I profile (Fig. 2). The dated material included mostly peat with fairly numerous macroremains, chiefly tree branch fragments. 
According to the radiocarbon analysis result, i.e., $3410 \pm 90$ years BP (1938-1509 cal BC), the sedimentation of deposits containing molluscan fauna began in Busko-Zdrój in the upper part of the Subboreal Phase. The second indication used as a basis to determine the deposit age were the pottery shards and brick fragments found in the topmost sections of profiles Bs-I, Bs-II, and Bs-III. These artefacts date back to the end of the Middle Ages. The nail from the topmost part of the Bs-I profile can also be associated with that period. The occurrence of certain molluscan species, especially the anthropogenic migrants whose date of entry into Poland is well established, is also a useful clue in determining the age of deposits.

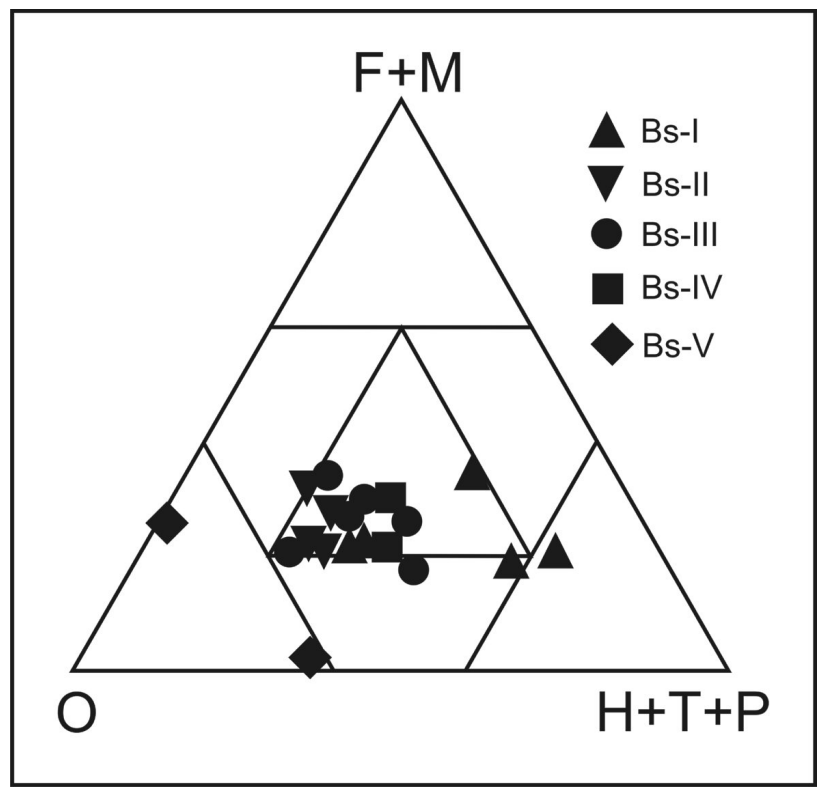

Fig. 4. Three-component diagram of malacofauna from profiles in Busko-Zdrój.

$\mathrm{F}$ - shade-loving species, $\mathrm{O}$ - species of open spaces (meadow species), $\mathrm{M}$ - mesophilous species, $\mathrm{H}$ - hygrophilous species, $\mathrm{T}$ - species of episodic bodies of water, $\mathrm{P}$ - species of permanent bodies of water

The presented profiles of Late Holocene deposits from Busko-Zdrój and the malacofauna contained in them document the history of this area from the upper part of the Subboreal Phase till historical times. The peat and dark mud with peat intercalations forming the Bs-I profile bottom are the oldest element. They most likely represent the close of the Subboreal Phase. Such age interpretation is supported by the result of radiocarbon dating $(3410 \pm 90$ years BP $(1938-1509$ cal BC) $)$ and the lack of pottery shards, which are abundant in the higher sections. The malacofauna indicates that the studied deposits were formed in a humid or waterlogged, open-space environment. The lack of forests and shaded habitats 
can be associated with either high humidity or prior deforestation, which was probably brought about by human activity. The Nida Basin area has been inhabited by human groups since the Palaeolithic. The increase in population along with the introduction of farming resulted in an extensive deforestation and substantial environmental changes. These processes have been documented in numerous sites in southern Poland (S.W. Alexandrowicz et al. 1997, W.P. Alexandrowicz \& Gołas-Siarzewska 2011, 2013 (in print), W.P. Alexandrowicz 2013 (in print)). The close of the Subboreal Phase is often associated with the formation of small peat bogs, especially in the deforested bottoms of valleys (Broda 1985, S.W. Alexandrowicz et al. 1997, Klimek et al. 2006). This phenomenon is clearly evident in the bottom part of the Bs-I profile. The Bs-II bottom section represents a similar period. Both these sites are located near one another and the malacofauna they contain is largely alike. A slightly elevated proportion of hygrophilous and aquatic forms in the Bs-I profile is undoubtedly due to the occurrence of more humid microhabitats.

The uppermost parts of the Bs-I and Bs-II profiles, as well as the Bs-III, Bs-IV and Bs-V profiles represent historical times. This is demonstrated by numerous pottery shards and crushed brick fragments. These deposits can be related to the fast development of the settlement at Busko that took place in late medieval times. It is a warm and humid climatic phase - Medieval Warm Period (Grove \& Switsur 1994, Huges \& Diaz 1994, Bradley 2000, Briffa 2000 , Jones \& Mann 2004), which favoured the emergence of humid biotopes on flat valley bottoms subject to a relatively weak anthropogenic impact.

Malacofauna found in the above-described profiles is largely composed of common forms represented in the current fauna inhabiting the Nida Basin. Compositionally and structurally similar molluscan assemblages have been described in numerous Upper Holocene sites in the Cracow region (S.W. Alexandrowicz 1983, S.W. Alexandrowicz et al. 1997, W.P. Alexandrowicz 2004), as well as the Nida Basin (W.P. Alexandrowicz \& GołasSiarzewska 2011, 2013 (in print)). Particularly noteworthy, however, is the occurrence of several rare species. Primarily Vallonia eniensis should be mentioned in this group. It is a moisture-loving species found in only several Holocene deposit sites (W.P. Alexandrowicz 1999, 2004, 2007) and currently occurring in just a few sites in Poland, mainly in the Świętokrzyskie Mountains, Małopolska Upland, and Nida Basin (Wiktor 2004). Other interesting species are Cecilioides acicula and Cepaea vindobonensis. The former is a form characteristic of farmland, occurring in the cracks of ploughed soil. Its appearance is indicative of the presence of arable land in a particular area (S.W. Alexandrowicz et al. 1997, W.P. Alexandrowicz 2004). The latter species is an anthropogenic migrant brought to Poland in the Middle Ages (W.P. Alexandrowicz \& S.W. Alexandrowicz 2010).

The Busko-Zdrój site with Late Holocene deposits containing malacofauna represents a good example of the application of malacological analysis in palaeogeographic reconstructions of small areas. Such reconstructions enable the description of local habitats, which is often impossible when using other methods.

This study has been sponsored by AGH University of Science and Technology through the University grant no 11.11.140.173. 


\section{REFERENCES}

Alexandrowicz S.W., 1983. Malacofauna of Holocene calcareous sediments of the Cracow Upland. Acta Geologica Polonica, 33, 117-158.

Alexandrowicz S.W., 1987. Analiza malakologiczna w badaniach osadów czwartorzędowych. Geologia, Kwartalnik AGH, 12, 1-2, 3-240.

Alexandrowicz S.W. \& Alexandrowicz W.P., 2011. Analiza malakologiczna. Metody badań i interpretacji. Rozprawy Wydziału Przyrodniczego PAU, 3, 5-302.

Alexandrowicz S.W., Bałaga K. \& Dobrowolski R., 1994. Etapy rozwoju torfowiska kopułowego Krzywice w okolicach Chełma Lubelskiego. Geologia, Kwartalnik AGH, 20, 3, 259-273.

Alexandrowicz S.W., Alexandrowicz W.P., Krąpiec M. \& Szychowska-Krąpiec E., 1997. Zmiany środowiska południowej Polski w okresie historycznym. Geologia, Kwartalnik AGH, 23, 4, 339-387.

Alexandrowicz W.P., 1997. Malakofauna osadów czwartorzędowych i zmiany środowiska naturalnego Podhala w młodszym Vistulianie i holocenie. Folia Quaternaria, 68, 7-132.

Alexandrowicz W.P., 1999. Evolution of the malacological assemblages in North Poland during the Late Glacial and Early Holocene. Folia Quaternaria, 70, 39-69.

Alexandrowicz W.P., 2004. Molluscan assemblages of Late Glacial and Holocene calcareous tufa in Southern Poland. Folia Quaternaria, 75, 3-309.

Alexandrowicz W.P., 2007. Malakofauna późnoglacjalnych i holoceńskich węglanowych osadów jeziornych północnej Polski. Geologia, Kwartalnik AGH, 33, 395-420.

Alexandrowicz W.P., 2013. Molluscan communities in Late Holocene fluvial deposits as an indicator of human activity. A study in Podhale Basin (South Poland). Ekologia Bratislava, 32, 111-125.

Alexandrowicz W.P. \& Alexandrowicz S.W., 2010. Expansive migrations of molluscs during the historic period. Biological Invasions in Poland, 1, 19-44.

Alexandrowicz W.P. \& Gołas-Siarzewska M., 2011. Środowisko sedymentacyjne martwic wapiennych w Pińczowie. VI Świętokrzyskie Spotkania Geologiczno-Geomorfologiczne. Materiaty Konferencyjne, 8-11.

Alexandrowicz W.P. \& Gołas-Siarzewska M., 2013. Zmiany środowiska Niecki Nidziańskiej (południowa Polska) w świetle analizy malakologicznej martwic wapiennych w Pińczowie. Biuletyn Państwowego Instytutu Geologicznego [in print].

Bradley R.S., 2000. Past global changes and their significance for the future. Quaternary Science Reviews, 19, 391-402.

Briffa K.R., 2000. Annual climate variability in the Holocene: interpreting the message of ancient trees. Quaternary Science Reviews, 19, 87-105.

Broda J., 1985. Proces wylesień na ziemiach polskich od czasów najdawniejszych. Czasopismo Geograficzne, 56, 2, 151-172.

Cabaj W. \& Nowak W.A., 1986. Rzeźba Niecki Nidziańskiej. Studia Ośrodka Dokumentacji Fizjograficznej, 14, 119-209. 
Dobrowolski R., Hajdas I., Melke J. \& Alexandrowicz W.P. 2005. Chronostratigraphy of calcareous mire sediments at Zawadówka (Eastern Poand) and their use in palaeogeographical reconstruction. Geochronometria, 24, 69-79.

Dobrowolski R., Pidek I.A., Alexandrowicz W.P., Hałas S., Pazdur A., Piotrowska N., Buczek A., Urban D. \& Melke J., 2012. Interdisciplinary studies of spring mire deposits from Radzików (South Podlasie Lowland, East Poland) and their significance for palaeoenvironmental reconstructions. Geochronometria, 39, 10-29.

Grove J.M. \& Swistur R., 1994. Glacial geological evidence for the Medieval Warm Period. Climatic Change, 26, 143-169.

Hughes M.K. \& Diaz H.F., 1994. Was there a 'Medieval Warm Period' and if so, when and where? Climatic Change, 26,109-142.

Jones P.D. \& Mann M.E., 2004. Climate over past millennia. Reviews of Geophysics, 42, 1-42.

Klimek K., Łanczont M. \& Nogaj-Chachaj J., 2006. Historical deforestation as a cause of alluviation in small valleys, subcarpathian loess plateau, Poland. Regional Environmental Change, 6, 52-61.

Ložek V., 1964. Quartärmollusken der Tschechoslovakei. Rozpravy Ustředniho Ustavu Geologického, 31, 3-374.

Ložek V., 2000. Palaeoecology of Quaternary Mollusca. Antropozoikum, 24, 35-59.

Piechocki A., 1979. Mięczaki (Mollusca). Ślimaki (Gastropoda). Fauna słodkowodna Polski, 7, 7-187.

Piechocki A. \& Dyduch-Falniowska A., 1993. Mięczaki (Mollusca), Małże (Bivalvia). Fauna Stodkowodna Polski, 7a, 7-200.

Radłowska J., 1966. Z geomorfologii okolic Pińczowa. Prace Geograficzne Instytutu Geografii PAN, 47, 17-37.

Rutkowski J., 1986. Budowa geologiczna Niecki Nidziańskiej. Studia Ośrodka Dokumentacji Fizjograficznej, 14, 35-61.

Wiktor A., 2004. Ślimaki lqdowe Polski. Wydawnictwo Mantis, Olsztyn. 